\title{
PROFIL PENYANDANG EPILEPSI DI POLIKLINIK SARAF RSUP PROF. DR. R.D. KANDOU MANADO PERIODE JUNI 2013 - MEI 2014
}

\author{
${ }^{1}$ Rhiza Khasanah \\ ${ }^{2}$ Corry N. Mahama \\ ${ }^{2}$ Theresia Runtuwene
}

\author{
${ }^{1}$ Kandidat Skripsi Fakultas Kedokteran Univerversitas Sam Ratulangi Manado \\ ${ }^{2}$ Bagian Neurologi Fakultas Kedokteran Universitas Sam Ratulangi Manado \\ Email: rkhazanah@yahoo.com
}

\begin{abstract}
Epilepsy is one of the oldest neurological diseases, found in all ages, and can cause impairment and mortality. Epilepsy is still a major public health problem, not only because of its health implications but also for its connotations in social, cultural, psychological, and economic life. This study aimed to obtain a description of patients with epilepsy in Neurology Clinic of Prof. Dr. RD Kandou Manado General Hospital, period of June 2013 - May 2014. The method used in this study was descriptive retrospective. The results showed that the number of epileptic patients was higher in males than in females. By the age group age, it was found that epileptic patients in young adult age group were the most frequent. By the level of education, it was found that patients with epilepsy were more common high school graduated. By the type of work; it was found that a lot of patients with epilepsy had no ocuupation yet and were still students/college students. Patients with partial seizure type (focal) epilepsy were the most commonly found. By past medical history, it was found that most patients had experienced seizures. The most common treatment for epileptic patients was monotherapy antiepileptic drugs..
\end{abstract}

Keywords: epilepsy, seizure

\begin{abstract}
Abstrak: Epilepsi adalah salah satu penyakit neurologi tertua, ditemukan pada semua umur dan dapat menyebabkan hendaya serta mortalitas. Epilepsi masih menjadi masalah kesehatan masyarakat yang utama, bukan hanya karena implikasi kesehatan tetapi juga untuk konotasi sosial, budaya, psikologis dan ekonomi. Penelitian ini bertujuan untuk memperoleh gambaran penyandang epilepsi di Poliklinik Saraf RSUP Prof. DR. R. D. Kandou Manado periode Juni 2013 - Mei 2014. Penelitian ini bersifat deskriptif retrospektif. Hasil penelitian menunjukkan penyandang epilepsi laki-laki lebih banyak dibandingkan dengan perempuan. Berdasarkan golongan usia, terbanyak ditemukan pada golongan usia dewasa muda. Berdasarkan tingkat pendidikan, terbanyak ditemukan pada lulusan SMA. Dilihat dari jenis pekerjaannya, banyak penyandang epilepsi yang belum bekerja dan masih berstatus sebagai pelajar/mahasiswa. Penyandang epilepsi dengan jenis bangkitan parsial (fokal) paling banyak ditemukan dari pada penyandang epilepsi dengan jenis bangkitan umum. Berdasarkan riwayat penyakit dahulu terbanyak terdapat pada riwayat penyakit dahulu dengan kejang. Pengobatan tersering yang dilakukan terhadap penyandang epilepsi ialah dengan monoterapi obat-obat anti epilepsi.
\end{abstract}

Kata kunci: epilepsi, kejang

Epilepsi adalah salah satu penyakit neurologi tertua, ditemukan pada semua umur dan dapat menyebabkan hendaya serta mortalitas. Diduga terdapat sekitar 50 juta orang dengan epilepsi di dunia. ${ }^{1}$ Epilepsi menempati urutan kedua dari 
penyakit saraf setelah stroke. ${ }^{2}$ Hampir $80 \%$ orang dengan epilepsi ditemukan dinegaranegara berkembang, di mana epilepsi masih menjadi masalah kesehatan masyarakat yang utama, bukan hanya karena implikasi kesehatan tetapi juga untuk konotasi sosial, budaya, psikologis, dan ekonomi. ${ }^{3}$

Prevalensi di negara sedang berkembang ditemukan lebih tinggi dari negara maju. Dilaporkan prevalensi di negara maju berkisar antara 4-7 per 1000 orang dan 5-74 per 1000 orang di Negara sedang berkembang. ${ }^{4} \mathrm{Di}$ Indonesia belum ada data yang pasti mengenai penderita epilepsi, tetapi diperkirakan ada 1-2 juta penderita epilepsi. Prevalensi epilepsi di Indonesia adalah 5-10 kasus per 1.000 orang dan insiden 50 kasus per 100.000 orang per tahun. ${ }^{5}$

Walaupun penyakit ini telah dikenal lama dalam masyarakat, terbukti dengan adanya istilah-istilah bahasa daerah untuk penyakit ini seperti sawan, ayan, sekalor, dan celengan, tapi pengertian akan penyakit ini masih kurang bahkan salah sehingga penderita digolongkan dalam penyakit gila, kutukan dan turunan sehingga penderita tidak diobati atau bahkan disembunyikan. ${ }^{2}$ Sehingga banyak di antara para penyandang epilepsi tidak mendapat perhatian selayaknya. Di kalangan dokter pun masih banyak yang belum memahami benar masalah epilepsi. Hal ini sangat disayangkan, lebih-lebih kalau diingat bahwa sebagaian besar penyandang epilepsi akan dapat sekolah, bahkan dapat meraih gelar sarjana dan dapat bekerja serta hidup bahagia apabila serangan-serangan dapat dicegah. ${ }^{6}$

\section{METODE PENELITIAN}

Metode yang digunakan dalam penelitian ini bersifat deskriptif retrospektif, yaitu dengan mengambil dan mengumpulkan data penyandang Epilepsi yang tercatat dari catatan rekam medik RSUP Prof. Dr. R. D. Kandou Manado periode Juni 2013-Mei 2014. Waktu penelitian dilakukan bulan Oktober 2014 sampai dengan desember 2014. Tempat penelitian dilakukan di Poliklinik Saraf
RSUP Prof. Dr. R. D. Kandou Manado. Populasi ialah seluruh pasien epilepsi yang datang di Poliklinik Saraf RSUP Prof. Dr. R. D. Kandou Manado. Sampel yang digunakan ialah pasien epilepsi yang datang di Poliklinik Saraf RSUP Prof. DR. R. D. Kandou Manado periode Juni 2013 Mei 2014 dan memenuhi kriteria inklusi yaitu memiliki catatan rekam medik, meliputi: biodata pasien (nama, umur, jenis kelamin), status kesehatan pasien (riwayat penyakit dahulu, terapi pengobatan), dan status sosial ekonomi (pendidikan, pekerjaan).

Variabel penelitian diantaranya jenis kelamin, umur, tingkat pendidikan, jenis pekerjaan, riwayat penyakit dahulu, jenis bangkitan dan terapi pengobatan.

\section{HASIL PENELITIAN DAN BAHASAN}

Berdasarkan hasil penelitian yang dilakukan terhadap penyandang epilepsi di Poliklinik Saraf RSUP Prof. Dr. R. D. Kandou periode Juni 2013 - Mei 2014 diperoleh data yang disajikan dalam bentuk tabel distribusi frekuensi.

Pada distribusi berdasarkan jenis kelamin didapatkan jumlah penyandang epilepsi laki - laki sebanyak 58 orang (57,4\%) dan jumlah penyandang epilepsi perempuan sebanyak 43 orang (42,6\%). Hal ini menunjukkan bahwa penyandang epilepsi lebih banyak ditemukan pada laki laki dibandingkan perempuan.

Tabel 1. Distribusi penyandang epilepsi berdasarkan jenis kelamin

\begin{tabular}{ccc}
\hline $\begin{array}{c}\text { Jenis } \\
\text { Kelamin }\end{array}$ & $\mathrm{N}$ & $\%$ \\
\hline Laki-laki & 58 & 57,4 \\
Perempuan & 43 & 42,6 \\
Total & 101 & 100 \\
\hline
\end{tabular}

Pada Tabel 2 dapat dilihat bahwa distribusi umur pasien penyandang epilepsi terbanyak pada golongan umur 15 - 24 tahun sebanyak 34 orang (33,7\%), kemudian diikuti oleh dua golongan umur yang jumlah penderitanya sama yaitu golongan umur $<15$ tahun, 35 - 44 tahun 
yaitu sebanyak 16 orang (15,8\%), lalu diikuti oleh golongan umur 45 - 54 tahun 14 orang $(13,9 \%)$, pada golongan umur 25 34 tahun 13 orang (12,9\%), 55 - 64 tahun 5 orang (5,0\%), 65 - 74 tahun 2 orang (2,0\%) dan jumlah penyandang epilepsi paling sedikit ditemukan pada golongan umur $\geq$ 75 tahun yaitu sebanyak 1 orang (1,0\%).

Tabel 2. Distribusi penyandang epilepsi berdasarkan golongan umur

\begin{tabular}{ccc}
\hline Golongan umur & $\mathrm{n}$ & $\%$ \\
\hline$<15$ & 16 & 15,8 \\
$15-24$ & 34 & 33,7 \\
$25-34$ & 13 & 12,9 \\
$35-44$ & 16 & 15,8 \\
$45-54$ & 14 & 13,9 \\
$55-64$ & 5 & 5 \\
$65-74$ & 2 & 2 \\
$\geq 75$ & 1 & 1 \\
Total & 101 & 100 \\
\hline
\end{tabular}

Pada Tabel 3 dapat dilihat distribusi penyandang epilepsi berdasarkan tingkat pendidikan paling banyak ditemukan pada tingkat pendidikan SMA sejumlah 53 orang (52,5\%), diikuti SMP 22 (21,8\%), SD 13 orang $(12,9 \%)$, S1 12 orang $(11,9 \%)$, dan S2 1 orang $(1,0 \%)$.

Tabel 3. Distribusi penyandang epilepsi berdasarkan tingkat pendidikan

\begin{tabular}{ccc}
\hline $\begin{array}{c}\text { Tingkat } \\
\text { Pendidikan }\end{array}$ & N & $\%$ \\
\hline SD & 13 & 12,9 \\
SMP & 22 & 21,8 \\
SMA & 53 & 52,5 \\
S1 & 12 & 11,9 \\
S2 & 1 & 1 \\
Total & 101 & 100 \\
\hline
\end{tabular}

Berdasarkan distribusi menurut jenis pekerjaan pada Tabel 4 menunjukkan bahwa penyandang epilepsi banyak ditemukan pada pelajar/mahasiswa dengan jumlah 44 orang (43,6\%). Dalam penelitian sebagian besar penyandang belum bekerja dan masih berstatus sebagai pelajar/mahasiswa, hal ini juga didasarkan pada golongan usia yang terbanyak. tetapi dapat dilihat juga penyandang yang sudah bekerja sebagian besar sebagai pegawai swasta, dan sebagian besarnya lagi sebagai ibu rumah tangga dan PNS.

Tabel 4. Distribusi penyandang epilepsi berdasarkan jenis pekerjaan

\begin{tabular}{ccc}
\hline Jenis Pekerjaan & $\mathrm{n}$ & Persen \\
\hline Pelajar/mahasiswa & 44 & 43,6 \\
Pegawai Negeri & 9 & 8,9 \\
Pegawai Swasta & 21 & 20,8 \\
Pensiunan & 3 & 3 \\
IRT & 10 & 9,9 \\
Tidak Bekerja & 3 & 3 \\
Lain - lain & 11 & 10,9 \\
Total & 101 & 100 \\
\hline
\end{tabular}

Dilihat dari jenis bangkitan epilepsi, hasil penelitian menunjukan bahwa penyandang epilepsi dengan jenis bangkitan parsial (fokal) berjumlah 55 orang (54,5\%), sedangkan penyandang epilepsi dengan jenis bangkitan umum sebanyak 41 orang (40,6\%), dan penyandang epilepsi dengan jenis bangkitan tak tergolongkan dengan jumlah 5 orang (5,0\%). Hasil ini memperkuat kepustakaan yang ada bahwa penyandang epilepsi dengan jenis bangkitan kejang parsial (fokal) lebih banyak dibandingkan dengan penyandang epilepsi dengan jenis bangkitan mum. ${ }^{6}$

Tabel 5. Distribusi penyandang epilepsi berdasarkan jenis bangkitan

\begin{tabular}{ccc}
\hline Jenis Bangkitan & $\mathrm{n}$ & $\%$ \\
\hline Bangkitan parsial & 55 & 54,5 \\
Bangkitan Umum & 41 & 40,6 \\
Bangkitan tak & & \\
tergolongkan & 5 & 5 \\
Total & 101 & 100 \\
\hline
\end{tabular}

Riwayat penyakit dahulu paling banyak ditemukan ialah riwayat kejang sebanyak 36 orang (41,9\%), diikuti riwayat trauma kepala 31 orang $(36,0 \%)$, dan 
kejang demam 19 orang (22,1\%). Kemungkinan anak tanpa kejang demam untuk terkena epilepsi adalah antara $0,5 \%$ sedangkan mereka yang pernah mengalami kejang demam kemungkinan ini naik sekitar 4 kali. $^{7}$

Tabel 6. Distribusi penyandang epilepsi berdasarkan riwayat penyakit dahulu

\begin{tabular}{ccc}
\hline $\begin{array}{c}\text { Riwayat Penyakit } \\
\text { Dahulu }\end{array}$ & $\mathrm{N}$ & $\%$ \\
\hline Kejang & 36 & 41,9 \\
Kejang Demam & 19 & 22,1 \\
Riwayat Trauma & & \\
Kepala & 31 & 36 \\
Total & 101 & 100 \\
\hline
\end{tabular}

Tabel 7. Distribusi penyandang epilepsi berdasarkan terapi pengobatan

\begin{tabular}{ccc}
\hline Terapi Pengobatan & $\mathrm{n}$ & $\%$ \\
\hline Asam valproat & 8 & 7,9 \\
Fenitoin & 48 & 47,5 \\
karbamazepin & 32 & 31,7 \\
fenobarbital & 1 & 1 \\
fenitoin dan & & \\
karbamazepin & 3 & 3 \\
asam valproat dan \\
karbamazepin \\
fenitoin dan asam \\
valproat \\
fenitoin dan \\
fenobarbital \\
Total
\end{tabular}

Pada Tabel 7 dapat dilihat distribusi penyandang epilepsi berdasarkan terapi pengobatan paling banyak digunakan obat fenitoin sebanyak 48 orang $(47,5 \%)$, diikuti karbamazepin 32 orang (31,7\%), asam valproat 8 orang $(7,9 \%)$, fenitoin dan asam valproat 5 orang $(5,0 \%)$, fenitoin dan karbamazepin 3 orang (3,0\%), kemudian diikuti 2 terapi kombinasi yang jumlahnya sama yaitu asam valproat dan karbamazepin, fenitoin dan fenobarbital yaitu sebanyak 2 orang (2,0\%) dan yang paling sedikit fenobarbital 1 orang (1,0\%). Fenitoin dan karbamazepin adalah OAE (obat anti epilepsi) lini pertama yang banyak digunakan dalam pengobatan epilepsi dan banyak tersedia sehingga digunkaan secara luas. $^{8}$

\section{SIMPULAN}

Berdasarkan penelitian yang dilakukan di Poliklinik Saraf RSUP Prof. DR. R. D. Kandou Manado periode Juni 2013 - Mei 2014, dapat disimpulkan sebagai berikut:

1. Penyandang epilepsi laki - laki lebih sering ditemukan daripada perempuan.

2. Golongan umur terbanyak ditemukan pada usia dewasa muda dan menurun pada lanjut usia.

3. Tingkat pendidikan lebih banyak ditemukan pada lulusan SMA.

4. Banyak penyandang epilepsi yang belum bekerja dan masih berstatus sebagai pelajar/mahasiswa dan merupakan golongan yang terbanyak, tetapi ditemukan juga sebagian besar penyandang yang bekerja sebagai pegawai swasta.

5. Jenis bangkitan parsial ( fokal ) paling banyak ditemukan daripada jenis bangkitan umum

6. Terbanyak dengan riwayat penyakit dahulu adanya kejang.

7. Pengobatan tersering yang dilakukan terhadap penyandang epilepsi ialah dengan monoterapi obat-obat anti epilepsi.

\section{SARAN}

Perlu adanya pemberian informasi yang benar kepada masyarakat umum tentang penyakit epilepsi sehingga tidak ada lagi pandangan negatif dari masyarakat terhadap penyandang epilepsi. Keluarga dan penyandang epilepsi tidak perlu merasa malu untuk memeriksakan diri dan mendapatkan pengobatan.

Penelitian tentang penyakit epilepsi harus terus dilakukan, untuk membantu pengetahuan para praktisi medis tentang penyakit epilepsi dan pengobatan yang efektif bagi penyandang

\section{DAFTAR PUSTAKA}

1. WHO [Internet]. Epilepsy: WHO fact sheet ; 2012. Available from: 
http://www.who.int/mediacentre/facts heets/fs999/en.

2. Tjahjadi P, Dikot Y, Gunawan $D$. Gambaran umum mengenai epilepsi. Dalam: Harsono. Kapita selekta neurologi. Ed ke-2. Yogyakarta: Gajah Mada University Press; 2009. 119-33.

3. Luce PY, Dismand H, Fabrice Q, et.al. Understanding the differences in prevalence of epilepsy in tropical regions. Epilepsia. 2011;52:13761381.

4. Ngugi AK, Bottomley C, Kleinschmidt I et.al. Estimation of the burden of active and life time epilepsy: A meta analytic approach. Epilepsia 2010;51(5): 883-90.
5. Harsono. Buku ajar neurologi klinis. Yogyakarta: Gajah Mada University Press; 2008. 119-33.

6. Mardjono M, Sidharta P. Neurologi Klinik dasar. Jakarta: Dian Rakyat; 2009.439-50.

7. Ahmed Z, Spencer S.S : An Approach to the Evaluation of a Patient for Seizures and Epilepsy, Wisconsin Medical Journal, 103(1): 49-55.

8. Tate SK, Depondt C, Sisodiya SM, et al. Genetic predictors of the maximum doses patients receive during clinical use of the anti-epileptic drugs carbamazepine and phenytoin. PNAS 2005;102(15):5507-12. 